\title{
ASPEK REPRODUKSI UDANG METAPENAEUS DI PERAIRAN KABUPATEN BATANG DAN KENDAL
}

\author{
Wiwiet Teguh Taufania,", Anhar Solichina, Suradi Wijaya Saputra ${ }^{a}$, Abdul Ghofar \\ ${ }^{a}$ Program Studi Manajemen Sumberdaya Perairan, Departemen Sumberdaya Akuatik \\ Fakultas Perikanan dan Ilmu Kelautan Universitas Diponegoro \\ J1. Prof. Sudharto, SH Kampus Undip Tembalang, Semarang 50275 \\ *Koresponden penulis : wietteguh@gmail.com
}

\begin{abstract}
Abstrak
Penelitian ini bertujuan untuk mendapatkan gambaran mengenai aspek reproduksi udang Metapenaeus di perairan Kabupaten Batang dan Kendal. Kabupaten Batang dan Kendal merupakan salah satu pusat penangkapan udang yang ada di perairan pantai utara. Harapannya sampel dari kedua kabupaten tersebut dapat mewakili gambaran aspek reproduksi udang Metapenaeus yang ada di perairan tersebut. Metapenaeus merupakan salah satu genus pada udang ekonomis penting dimana persebarannya hampir di seluruh perairan pantai utara. Tingkat eksploitasi yang berlebihan akan mengakibatkan menipisnya sumberdaya yang ada. Oleh karena itu, perlu dilakukannya penelitian mengenai aspek reproduksi udang agar memberikan informasi lebih mengenai gambaran kondisi sumberdaya udang Metapenaeus yang ada di perairan tersebut. Adapun variabel penelitian antara lain: komposisi spesies dari genus Metapenaeus, struktur ukuran, ukuran pertama kali tertangkap $\left(\mathrm{LC}_{50 \%}\right)$, nisbah kelamin dan tingkat kematangan gonad. Pengambilan sampel dilakukan dari bulan Juni - September 2017. Hasil penelitian menunjukkan bahwa jenis Metapenaues yang tertangkap antara lain: $M$. ensis, M. tenuipes, M. moyebi, M. conjunctus dan $M$. affinis dengan TKG rata-rata $0-2$. Kesimpulan dari penelitian ini adalah mayoritas Metapenaeus yang tertangkap masih dalam kondisi belum matang gonad sehingga perlu diadakannya sosialisasi mengenai penangkapan yang lestari.
\end{abstract}

Kata kunci: Metapenaeus, Kabupaten Batang, Kabupaten Kendal, Reproduksi

\begin{abstract}
Abstact
This study aims to obtain an overview of the reproductive aspects of Metapenaeus in Batang and Kendal waters. Batang and Kendal Regency is one of the shrimp fishing centers in the northern coast waters. The assumption is that samples from two districts can represent an overview reproductive aspect of metapenaeus in these waters. Metapenaeus is one genus in economically important shrimp where the distribution is almost in all north coast waters. Over exploitation will result in depletion of existing resources. Therefore, it is necessary to conduct research on aspects of shrimp reproduction in order to provide more information about metapenaeus condition. The research variables include: species composition, size structure, size first caught $\left(L C_{50 \%}\right)$, sex ratio and gonad maturity level. Sampling was carried out from June to September 2017. The results showed that the types of Metapenaues caught were: M. ensis, M. tenuipes, M. moyebi, M. conjunctus and M. affinis with the average 0 - 2 GML (Gonad Maturity Level). The conclusion is the majority of Metapenaeus caught are still in a gonadal immature condition so there needs to be a socialization of sustainable fishing.
\end{abstract}

Keywords: Metapenaeus, Batang Regency, Kendal Regenc, Reproductive

\section{PENDAHULUAN}

Daerah pesisir merupakan salah satu sektor perikanan penting yang mampu untuk meningkatkan kesejahteraan masyarakatnya. Kabupaten Batang dan Kabupaten Kendal merupakan daerah pesisir dan berpotensi dalam perikanan, baik perikanan tangkap maupun budidaya. Sebagian besar penduduk di daerah pesisir merupakan nelayan. Hal ini bisa dilihat dari panjang garis pantai Kab. Batang 38,75 Km dan $41 \mathrm{Km}$ untuk Kab. Kendal [1].

Jenis udang penaeid merupakan udang yang memiliki potensi cukup tinggi di Perairan Indonesia. Daerah penyebaran udang cukup merata dari mulai kawasan perairan sebelah barat hingga ke kawasan 
Indonesia bagian timur meliputi perairan: Jawa, Sumatera, Papua, sebagian Maluku, Kalimantan dan Sulawesi Selatan. Untuk pengembangan penangkapan udang lebih dikhususkan pada kawasan Indonesia timur, karena perairan tersebut memiliki sumber daya ikan yang cukup potensial [2].

Oleh karena itu, agar udang dapat tetap lestari dan keseimbangan ekosistem tetap terjaga maka diperlukan suatu penelitian yang didasarkan pada hasil kajian yang salah satunya mengenai aspek biologi reproduksi. Informasi tentang aspek biologi reproduksi ini dapat dijadikan sebagai bahan pertimbangan dalam pengelolaan sumber daya perikanan.

\section{MATERI DAN METODE PENELITIAN}

Metode penelitian yang digunakan yaitu metode survei, yaitu penelitian ini dilakukan untuk memperoleh fakta-fakta dan mencari keterangan secara faktual mengenai produksi dan aspek biologi reproduksi udang Metapenaeus di perairan Kab. Batang dan Kendal.

\section{Pengambilan Sampel}

Metode atau teknik pengambilan sampel yang digunakan adalah simple random sampling (acak sederhana), yaitu proses pengambilan sampel dilakukan secara acak dengan tujuan memberi kesempatan yang sama pada setiap anggota populasi untuk menjadi anggota sampel. Apabila besarnya sampel yang diinginkan itu berbeda-beda, maka besarnya kesempatan bagi setiap satuan elementer untuk terpilih pun berbeda-beda [3]. Pengambilan sampel dilakukan 1 kali sebulan selama 4 bulan.

Pengambilan sampel dilakukan di TPI Roban (Kab. Batang), TPI Tawang (Kab. Kendal), dan TPI Bandengan (Kab. Kendal). Dipilihnya TPI tersebut dalam pengambilan sampel, dikarenakan lokasi tersebut mampu mewakili kegiatan perikanan pantai Kab. Roban dan Kendal. Setiap lokasi sampling diambil kapal sampel dengan mengikuti prosedur yang dikemukakan oleh [4], sebagai berikut :

a) Jika kapal yang mendarat kurang dari 5 (lima) buah, dipilih satu kapal yaitu kapal nomor satu; dan b) Jika kapal yang datang lebih dari 5 (lima) buah, maka dipilih 2 (dua) buah kapal sebagai kapal sampel. Kapal sampel pertama adalah kapal nomor urut 1 (satu) dari daftar nomor urut kapal. Kapal sampel kedua adalah kapal nomor 2 (dua) yang daerah penangkapannya berbeda dengan kapal nomor 1 (satu). Jika daerah penangkapannya sama dengan kapal nomor 1 (satu), maka kapal sampel kedua adalah kapal nomor berikutnya dengan daerah penangkapan yang berbeda dengan kapal nomor 1(satu), dan seterusnya jumlah kapal sampel mengikuti kelipatan 5 (lima).

\section{Analisis Data}

Analisis pertumbuhan dan kematangan gonad dilakukan dengan sistematik sampling yaitu sampel yang didapat dipisahkan berdasarkan interval-interval tertentu untuk mendapatkan suatu kelompok yang kemudian dilakukan analisa pada masing-masing kelompok dan nantinya akan memberikan hasil yang akan menjelaskan karakteristik dari kelompok-kelompok tersebut beserta hubungannya dengan fenomena lain [5].

Jenis kelamin diidentifikasi dengan melihat bentuk kelamin udang yang terletak di bagian ventral di antara kaki jalan (periopod) dan kaki renang (pleopod). Alat kelamin udang jantan disebut petasma, sedangkan alat kelamin betina disebut telycum [2].

Nisbah kelamin dihitung dengan cara membandingkan jumlah udang jantan dengan jumlah udang betina dari jumlah total sampel. Untuk pengujian perbandingan nisbah kelamin dengan menggunakan uji Chi-square [6], yaitu dengan hipotesis:

$\mathrm{H}_{0}$ : jika rasio udang jantan dan betina sama $\mathrm{H}_{1}$ : jika rasio udang jantan dan betina berbeda

Nilai perbandingan nisbah kelamin dengan menggunakan uji Chi-square dimana:

- $\mathrm{X}^{2}$ hitung $>\mathrm{X}^{2}$ tabel, maka tolak $\mathrm{H}_{0}$, terima $\mathrm{H}_{1}$

- $\mathrm{X}^{2}$ hitung $\leq \mathrm{X}^{2}$ tabel, maka terima $\mathrm{H}_{0}$, tolak $\mathrm{H}_{1}$

Rumus uji Chi-square dituliskan sebagai berikut:

$$
X^{2}=\frac{\sum(f o-f h)^{2}}{f h}
$$


Keterangan :

$\mathrm{X}^{2} \quad=$ Chi Kuadrat,

fo $\quad=$ Persentase hasil pengamatan,

fh $\quad=$ Persentase yang diharapkan

Penentuan TKG, dengan cara mengamati morfologi gonad yaitu mengamati bentuk gonad, ukuran gonad dan warna gonad. Pedoman yang digunakan adalah klasifikasi TKG udang Menurut Motoh dalam [5], membagi tingkat kematangan udang Penaeid menjadi lima tingkatan yaitu :

$\begin{array}{ll}\text { Tingkat } 0 & \text { : Ovari tipis, bening dan } \\ \text { tidak berwarna. } & \\ \text { Tingkat } 1 & \text { : Ovari membesar, bagian } \\ & \text { depan dan tengah } \\ \text { berkembang. } & \\ \text { Tingkat 2 } & \begin{array}{l}\text { Ovari berwarna hijau muda } \\ \text { dan dapat dilihat melalui } \\ \text { eksoskeleton, bagian depan } \\ \text { dan tengah berkembang }\end{array} \\ \text { penuh. }\end{array}$

Tingkat 3 : Ovari berwarna hijau tua. Ova lebih besar daripada tingkatan sebelumnya. Pada tingkatan ini dianggap sebagai tingkat kematangan telur.

Tingkat 4 : Ovari lembek dan kisut. Ova sudah dilepaskan, biasanya badan udang terasa lembek dan rongga bagian atas abdomen kosong

\section{HASIL DAN PEMBAHASAN}

\section{Komposisi}

Hasil penelitian yang dilakukan selama bulan Juni - September 2017 dengan sampel sebanyak 1944 ekor dari genus Metapenaeus yang didapatkan komposisi jenis antara lain: $M$. ensis; $M$. moyebi; $M$. tenuipes; $M$. conjunctus; $M$. siluensis; dan $M$. affinis. Dari data yang didapat, hanya $M$. moyebi dan $M$. affinis yang tidak dilakukan analisis lanjutan karena jumlah data yang sangat sedikit. Menurut [7] puncak pemijahan udang Penaid di perairan Cochin, India adalah pada bulan Juli - September. Sedangkan berdasarkan hasil penelitian [8] kelimpahan larva udang Metapenaeus di Perairan Pemangkat, Sambas, Kalimantan Barat dominan pada bulan Desember. Hasil penelitian [5] Metapenaus elegans di Segara Anakan, Cilacap diduga memijah dua kali dalam setahun dengan puncak April/Mei (awal Kemarau) dan Desember (awal Penghujan).

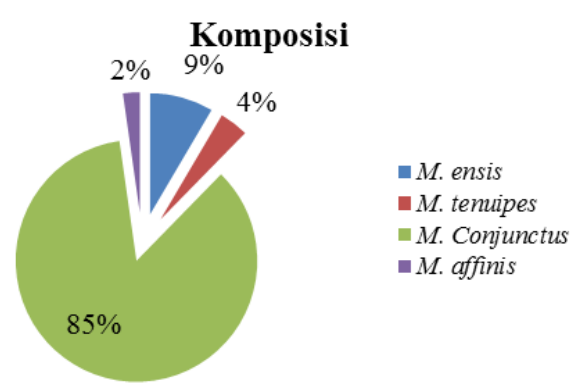

Gambar 1. Komposisi jenis Metapenaeus

Komposisi merupakan salah satu informasi penting yang dibutuhkan sebagai evaluasi dampak penangkapan udang [9]. Komposisi jenis Metapenaeus yang tertangkap dapat dilihat pada Gambar 1. Hasil menunjukkan bahwa jumlah terbanyak dari $M$. conjunctus $(85 \%)$ dan jumlah paling sedikit adalah $M$. affinis (2\%). Hal ini berbanding lurus dengan hasil penelitian [10] yang dilakukan di Perairan Batang dan Kendal bahwa hasil tangkapan udang yang tertangkap dengan alat tangkap didominasi oleh $M$. conjunctus. Tinggi rendahnya setiap jenis udang dapat saja terjadi dalam suatu ekosistem. Menurut [4] jika salah satu spesies mendominasi pada suatu ekosistem, berarti ada sesuatu yang terjadi pada ekosistem tersebut, mungkin disebabkan oleh spesies lain sudah tidak cocok lagi dengan kondisi yang ada

\section{Struktur Ukuran}

Gambaran struktur ukuran panjang total udang Metapenaeus selama 4 bulan sampling disajikan pada Gambar 2. Hasil menunjukkan bahwa jumlah udang yang paling banyak tertangkap adalah $M$. conjunctus dengan ukuran yang paling banyak tertangkap $90 \mathrm{~mm}$ sedangkan yang paling sedikit adalah $M$. affinis dengan ukuran yang paling banyak tertangkap 90 $\mathrm{mm}$. Keanekaragaman ukuran $M$. conjunctus paling bervariasi mulai ukuran kecil sampai besar $(55-130 \mathrm{~mm})$. Sedangkan M. ensis hanya ukuran kecil $(50-75 \mathrm{~mm})$ yang tertangkap. Hasil penelitian [10] yang dilakukan di Perairan Batang Kendal diketahui bahwa kisaran ukuran $M$. 
conjunctus di Perairan Batang dari ukuran terkecil $75 \mathrm{~mm}$ dan terbesar $189 \mathrm{~mm}$. Sedangkan ukuran $M$. conjunctus di Perairan Kendal mulai dari ukuran terkecil $54 \mathrm{~mm}$ dan terbesar $135 \mathrm{~mm}$. Menurut [10] setiap spesies udang Metapenaus yang tertangkap memiliki modus panjang yang berbeda. Udang melakukan banyak pergerakan yang membuat sulit untuk menemukan udang ukuran terkecil hingga terbesar dalam suatu tempat dan waktu yang sama, karena pada umumnya semua ukuran udang Metapenaus tidak berada dalam suatu tempat dan waktu yang sama dalam suatu perairan.

Ukuran Pertama Kali Tertangkap $\left(\mathrm{LC}_{\mathbf{5 0} \%}\right)$ Hasil pengukuran pertama kali tertangkap $\left(\mathrm{LC}_{50 \%}\right)$ tiap jenis kelamin dari masing-masing spesies dapat dilihat pada Gambar 3. Hasil perhitungan ukuran pertama kali tertangkap $\left(\mathrm{LC}_{50 \%}\right)$ menunjukkan bahwa udang jantan ( $M$. ensis dan $M$. tenuipes) tertangkap lebih kecil daripada betina. Sedangkan untuk $M$. conjunctus sebaliknya. Pada $M$. affinis hanya jantan yang tertangkap selama penelitian. Hasil penelitian [10] yang dilakukan di perairan Batang Kendal menyebutkan bahwa ukuran pertama kali tertangkap $\left(\mathrm{LC}_{50 \%}\right)$ udang jenis $M$. conjunctus jantan $77 \mathrm{~mm}$ dan betina $73 \mathrm{~mm}$. Hasil perhitungan ukuran udang jantan dan betina pertama kali tertangkap $\mathrm{LC}_{50 \%}<1 / 2 \mathrm{~L} \infty(88,5$ $\mathrm{mm}$ ). Hasil penelitian [11] yang di lakukan di perairan Selat Bangka menyebutkan bahwa berdasarkan analisis diperoleh panjang udang jenis $M$. ensis pertama kali tertangkap $\left(\mathrm{LC}_{50 \%}\right)$ jaring Trammel adalah $30,68 \mathrm{~mm}$. Menurut [5] secara keseluruhan nilai $\left(\mathrm{LC}_{50 \%}\right)$ yang didapatkan dari tiap spesies udang Metapenaeus tidak kurang dari setengah nilai L infinity-nya. L infinity ini diinterpretasikan sebagai rata-rata panjang udang pada umur yang sangat tua. Ukuran rata-rata udang Metapenaeus untuk setiap spesies berbeda. Hal ini dapat terjadi akibat pengaruh dari beberapa faktor. Salah satunya adalah faktor fisiologis dari tiap spesies, serta kondisi lingkungan seperti ketersediaan makana, arus, gelombang, kedalaman, suhu, kecerahan dan lain sebagainya. Selain itu, faktor alat tangkap yang digunakan merupakan alat tangkap yang tidak selektif.

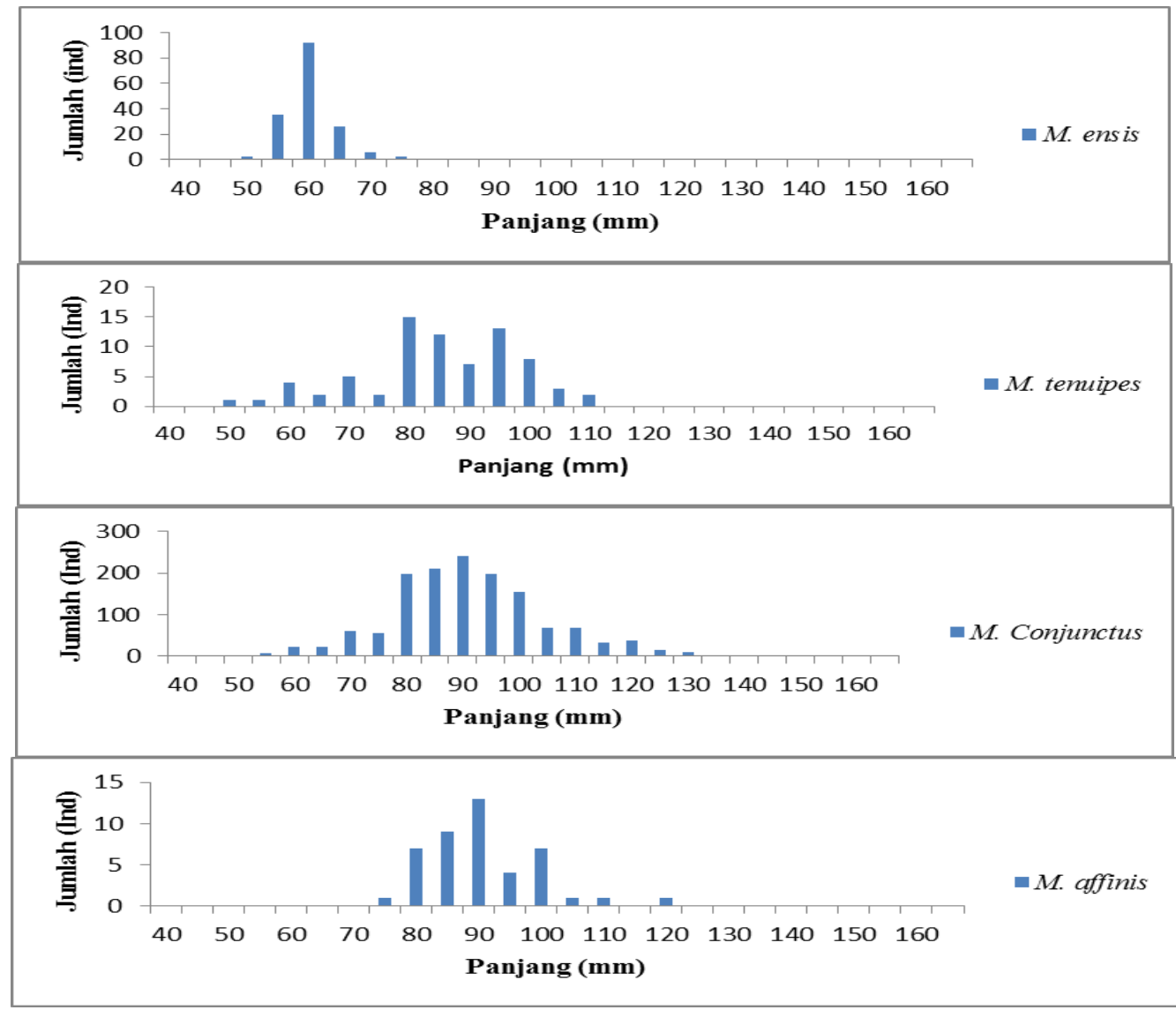

Gambar 2. Histogram Struktur Ukuran Setiap Jenis 


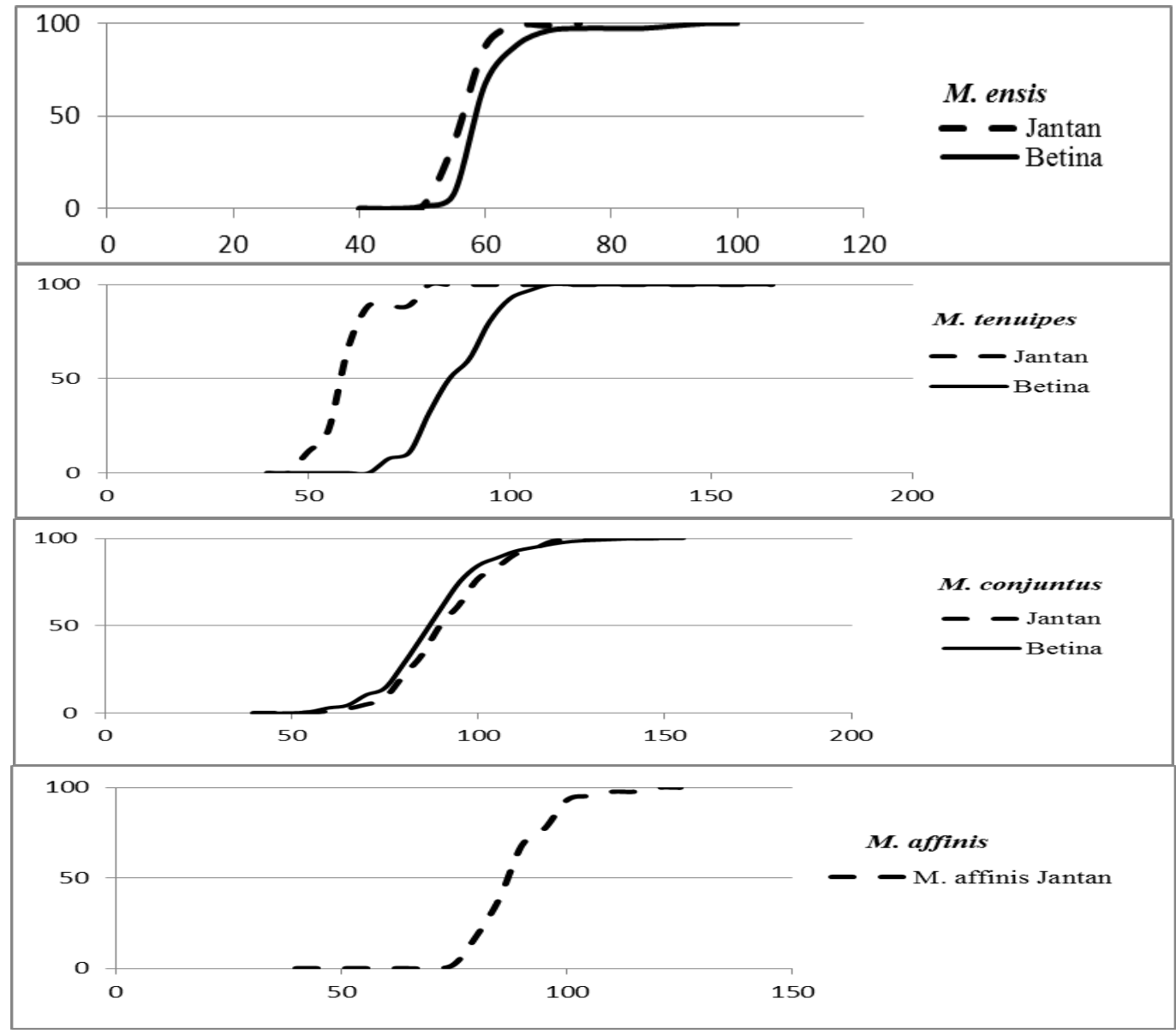

Gambar 3. Kurva Ukuran Pertama Kali Tertangkap Setiap Jenis

\section{Nisbah Kelamin}

Hasil pengamatan nisbah kelamin pada tiap spesies selama 4 bulan sampling dapat dilihat pada tabel di bawah ini.

Tabe 1. Nisbah Kelamin pada Setiap Spesies

\begin{tabular}{ccccc}
\multirow{2}{*}{ Jenis Kelamin } & \multicolumn{4}{c}{ Jumlah Individu } \\
\cline { 2 - 5 } & M. ensis & M. tenuipes & M. conjunctus & M. affinis \\
\hline Jantan & 88 & 9 & 971 & 44 \\
Betina & 77 & 66 & 689 & 0 \\
Ratio & $1,14: 1$ & $1: 7,33$ & $1,40: 1$ & $1: 0$ \\
\hline
\end{tabular}

Berdasarkan Tabel 1. dapat diketahui bahwa perbandingan jantan dan betina pada M. ensis, $M$. tenuipes, $M$. conjunctus dan $M$. affinis berturut-turut adalah $1,14: 1 ; 1: 7,33$; $1,40: 1$ dan 1 : 0 . Dari data tersebut menunjukan bahwa secara umum jumlah udang jantan lebih banyak dibandingkan jumlah udang betina, kecuali pada jenis $M$. tenuipes. Hasil penelitian [10] menunjukkan bahwa rasio nisbah kelamin udang jenis $M$. conjunctus jantan dan betina di Perairan
Kendal dan Batang berturut-turut adalah 1 : 1,$88 ; 1: 1,63$. Hasil penelitian [12] diketahui bahwa hasil nisbah kelamin udang $M$. conjunctus jantan dan betina di Perairan Batang dan Kendal berturut-turut 1:1,26 ; 1:1,52 dan M. tenuipes hanya ditemukan di Perairan Kendal dengan perbandingan Jantan dan Betina 1:1,86, dimana sama-sama dalam kondisi jumlah kelamin betina lebih banyak dibandingkan udang jantan. Tingginya rasio udang jantan dapat terjadi karena beberapa 
faktor seperti sifat genetik dan tempat. Menurut [4] bahwa rasio kelamin udang pada setiap tempat dipengaruhi oleh sifat genetikanya, diantaranya adalah ketahanan terhadap guncangan salinitas. Udang betina kurang tahan terhadap salinitas rendah dibandingkan udang jantan. Selain itu rasio kelamin udang akan mengalami perubahan tergantung tempat, pada perairan estuari udang jantan relatif lebih banyak jika dibandingkan udang betina, sedangkan di lepas pantai justru udang betina yang relatif lebih banyak.

\section{Tingkat Kematangan Gonad}

Persentase tingkat kematangan gonad selama penelitian pada setiap jenis tersaji pada Tabel 2. Ada 5 tingkatan dalam penentuan kematangan gonad, dalam hal ini TKG 0 - 2 dapat diartikan belum matang gonad, sedangkan $3-4$ dianggap sudah matang gonad (masak).

Tabel 2. Persentase TKG pada Setiap Spesies

\begin{tabular}{ccccccccc}
\multirow{2}{*}{ TKG } & \multicolumn{2}{c}{ M. ensis } & \multicolumn{2}{c}{ M. tenuipes } & \multicolumn{2}{c}{ M. conjunctus } & \multicolumn{2}{c}{ M. affinis } \\
\cline { 2 - 9 } & Jantan & Betina & Jantan & Betina & Jantan & Betina & Jantan & Betina \\
\hline 0 & 100 & 100 & 100 & 36,36 & 94,85 & 96,08 & 100 & - \\
1 & 0 & 0 & 0 & 21,21 & 1,03 & 1,74 & 0 & - \\
2 & 0 & 0 & 0 & 34,85 & 2,88 & 1,16 & 0 & - \\
3 & 0 & 0 & 0 & 7,58 & 1,24 & 0,73 & 0 & - \\
4 & 0 & 0 & 0 & 0,00 & 0,00 & 0,29 & 0 & - \\
\hline
\end{tabular}

Hasil pengamatan menunjukkan bahwa mayoritas udang yang tertangkap belum matang gonad. Hasil penelitian [12] menyebutkan bahwa mayoritas udang di Perairan Batang maupun Kendal dalam Kondisi belum matang gonad. Hasil penelitian [13] yang dilakukan di Perairan Cilacap pada bulan September-Desember diketahui bahwa ketiga udang Metapenaeus yang tertangkap (M. affinis, M. dobsoni, M. ensis) dan di daratkan pada TPI tersebut dalam keadaan belum matang Gonad. Menurut [5] bahwa Udang Metapenaeus di Perairan Cilacap melakukan pemijahan pada bulan September-Desember. Tingkat kematangan gonad dapat dipengaruhi oleh beberapa faktor seperti spesies, umur, ukuran dan faktor alam lainya. Menurut Anggraeni dalam [9] keadaan tersebut disebabkan oleh pergerakan udang sebagai udang penaeid untuk beruaya berdasarkan tingkat kedewasaan. Udang muda terdapat di daerah payau dekat pantai sedangkan udang dewasa terdapat di perairan yang lebih jauh dari pantai dengan kadar garam lebih tinggi. Jenis-jenis seperti Penaeus indicus, $M$. dobsoni, M. ensis dan M. mutatus akan memijah di laut lepas.
$\mathbf{L M}_{50 \%}$

Hasil pengamatan tingkat kematangan gonad baik untuk jantan maupun betina, hanya sedikit yang matang gonad (Tabel 2. Persentase TKG pada setiap spesies) sehingga, tidak bisa ditentukan nilai ukuran pertama kali matang gonad $\left(\mathrm{LM}_{50 \%}\right)$. Hasil penelitian [9] yang dilakukan di Perairan Cilacap diketahui bahwa ukuran pertama kali matang gonad udang $M$. affinis pada panjang karapas $51 \mathrm{~mm} \mathrm{M}$. dobsoni 46,5 $\mathrm{mm}$ dan $M$. ensis 58,5 $\mathrm{mm}$. Hasil penelitian [14] di Perairan Teluk Cempi Nusa Tenggara Barat diketahui bahwa udang jenis M. dobsoni pertama kali matang gonad $\left(\mathrm{LM}_{50 \%}\right)$ pada ukuran $24 \mathrm{~mm}$, dengan kisaran 23,8-24,2 $\mathrm{mm}$ dan ukuran pertama kali matang gonad $\left(\mathrm{LM}_{50 \%}\right)$ udang jenis $M$. affinis berkisar antara 26-26,4 mm dengan rata-rata $\mathrm{LM}_{50 \%}$ pada ukuran $26,2 \mathrm{~mm}$. Tingginya persentase udang yang belum matang gonad mengindikasikan tingginya tekanan penangkapan pada stok udang dan menjadi indikator sedikitnya jumlah udang ukuran dewasa. Menurut [4] sumber daya udang sekarang telah terjadi lebih tangkap (overfishing), terutama diakibatkan oleh karena lebih tangkap pertumbuhan (growth overfishing). Hal tersebut pada akhirnya akan mengakibatkan terjadinya recruitment overfishing karena tidak cukup tersedianya 
induk untuk memijah. Kematangan gonad udang dipengaruhi dua faktor yaitu faktor dalam dan luar. Faktor dalam antara lain spesies, umur dan ukuran, sedangkan faktor luar adalah suhu, arus dan curah hujan.

\section{KESIMPULAN}

Kesimpulan yang didapat dari penelitian ini adalah sebagai berikut:

1. Metapenaues yang tertangkap antara lain: M. ensis, M. tenuipes, M. moyebi, M. conjunctus dan M. affinis.

2. Mayoritas udang yang tertangkap belum matang gonad

\section{UCAPAN TERIMAKASIH}

Terima kasih kepada Dekan Fakultas Perikanan dan Ilmu Kelautan, Universitas Diponegoro yang telah membantu pendanaan penelitian melalui surat penugasan No: 2292/UN7.3.10/LT/2017 dengan sumber dana: Selain APBN DPA SUKPA Fakultas Perikanan dan Ilmu Kelautan, Universitas Diponegoro Tahun Anggaran 2017

\section{REFERENSI}

[1] BPS (Badan Pusat Statistik) Provinsi Jawa Tengah. 2014. Provinsi Jawa Tengah dalam Angka 2014. Jawa Tengah; BPS Provinsi Jawa Tengah. 2014.

[2] Chan, T.Y. Shrimps and Prawns. In. Carpenter KE and VH Niem, "The living marine resources of the Western Central Pacific," vol. 2, Food and Agriculture Organization of the United Nation. Rome. 1998. Available at http://www.fao.org/3/aw7192e/w7192e13.pdf (accessed on June 20, 2016)

[3] Notoatmodjo, S, "Metodologi Penelitian Kesehatan," Rineka Cipta, Jakarta, pp 207, 2002.

[4] Saputra, S.W, " Dinamika Populasi Ikan," Badan Penerbit Universitas Diponegoro, Semarang, 2009.

[5] Saputra, S. W, "Aspek Reproduksi dan
Daerah Pemijahan Udang Jari (Metapenaeus elegans de Man, 1970)," Jurnal Ilmu Kelautan., vol. 10, no. 1:4149, 2005.

[6] Pramonowibowo, "Kepadatan Udang Penaeid di Perairan Semarang dan Sekitarnya," Sekolah Pasca Sarjana Universitas Diponegoro, Semarang, pp. 35-56, 2003

[7] Easo, S dan Mathew, K. J, "Seasonal Variations in the Abundance of Penaeid Prawn Seed in Relation To Environmental Parameters in the Seed Ground of Cochin Backwaters," Indian J. Fish., vol. 36 No. 2, pp. 125-132, 1989.

[8] Tirtadanu, T., Suprapto, S. and Putri Pane, A. R, "Komposisi Jenis, Sebaran dan Kepadatan Stok Udang Pada Musim Selatan di Perairan Timur Kalimantan," Bawal Widya Riset Perikanan Tangkap., vol. 10 no. 1, p. 41.2018.

[9] Saputra, S. W., Solichin, A. and Rizkiyana, W, "Keragaman Jenis Dan Beberapa Aspek Biologi Udang Metapenaeus Di Perairan Cilacap, Jawa Tengah," Journal of Management of Aquatic Resources, vol. 3, pp. 37-46, 2013.

[10] Monica, C.N., Saputra, S.W. and Solichin,A, "Aspek Biologi Udang Metapenaeus di Perairan Batang Kendal, Jawa Tengah," Journal of Maquares., vol. 6 no. 4, pp 358-366, 2017.

[11] Lestari, P., Tirtadanu., Kembaen, D.D and Wedjatmiko, "Parameter Populasi Udang Dogol (Metapenaeus ensis De Hann, 1984) di Selat Bangka, Sumatera Selatan," Widya Riset Perikanan Tangkap., vol.10 no. 2, pp 135-143, 2018.

[12] Sari, V dan Solichin, A dan Saputra, S.W, "Komposisi dan Beberapa Aspek Biologi Spesies Udang Penaeid di Perairan Batang dan Kendal, Jawa Tengah," Journal of Maquares., vol. 6 no. 4, pp 423-432. 2017. 
[13] Soewardi, K., Arifin, O. Z., Hidayat, A, "Keragaman Genetik Udang Jari (Metapenaeus elegans De Man 1907) Berdasarkan Karakter Morfometrik di Laguna Segara Anakan, Cilacap, Jawa Tengah," Jurnal Ilmu-ilmu Perairan dan Perikanan Indonesia., vol. 13 no. 2, pp. 125-133, 2006
[14] Putri, M. R. A. dan Nastiti, A. S, "Beberapa Aspek Biologi Udang Banana (Metapenaeus dobsoni) dan Udang Kayu (M. affnis) di Perairan Teluk Cempi, Nusa Tenggara Barat," Bawal Widya Riset Perikanan Tangkap., vol. 9 no. 1. pp 1-10, 2017. 